\title{
Rozwój przemysłu poprzez inteligentne specjalizacje i instrumenty polityki regionalnej UE w województwie małopolskim
}

\section{The Development of Industry through Smart Specialisation and EU Regional Policy Instruments in Małopolskie Voivodeship (Poland)}

Streszczenie: Artykuł odpowiada na pytania, jakie jest miejsce sektora przemysłu w strategii rozwoju Unii Europejskiej i Polski oraz czy i w jakim stopniu polityka wsparcia innowacji poprzez inteligentne specjalizacje (IS) może przyczynić się do rozwoju przemysłu w polskich regionach. Badania obejmują analizę źródeł pierwotnych, takich jak dokumenty programowe i akty prawne UE i Polski, wykorzystano także dane statystyczne Eurostatu i Komisji Europejskiej oraz dane Ministerstwa Inwestycji i Rozwoju dotyczące wykorzystania funduszy UE, będących głównym źródłem współfinansowania IS. Analiza dokumentów strategicznych UE i Polski oraz danych statystycznych potwierdza rosnące znaczenie przemysłu dla rozwoju gospodarczego. Autorka dowodzi, że inteligentne specjalizacje niekoniecznie odzwierciedlają jednak wzrost względnej wagi danej branży (przemysłu), bardziej służą wspieraniu polityki innowacyjnej (koncentrują środki na działalność badawczo-rozwojową w pewnych obszarach) niż polityki przemysłowej. Ponadto fundusze polityki regionalnej pozwalają przedsiębiorstwom inwestować w rozwój zaawansowanych technologii, a przez to wpływają na modernizację przemysłu.

\begin{abstract}
The study aims to answer the questions: what is the place of the industrial sector in the European Union and Poland development strategy; and whether, and if so then to what extent, the policy to support innovation through smart specialisations can contribute to the development of industry in Polish regions. Research includes the analysis of primary sources, such as programming documents and EU and Polish legislation, Eurostat and EC statistical data, as well as data of the Ministry of Investment and Development regarding the use of EU funds being the main source of co-financing of smart specialisations. The analysis of EU and Polish strategic documents and statistical data confirms the growing importance of industry for economic development. The author argues that smart specialisations do not necessarily reflect an increase in the relative importance of a given industry, they are more conducive to supporting innovation policy (focusing resources on research and development activities in certain areas) than industrial policy. Moreover, regional policy funds allow enterprises to invest in the development of advanced technologies and thus influence the modernisation of industry.
\end{abstract}

Słowa kluczowe: polityka innowacyjna UE; polityka przemysłowa UE; polityka regionalna UE; regionalne inteligentne specjalizacje

Keywords: EU industrial policy; EU innovation policy; EU regional policy; regional smart specialisation 
Otrzymano: 11 grudnia 2018

Received: 11 December 2018

Zaakceptowano: 12 lutego 2019

Accepted: 12 February 2019

\section{Sugerowana cytacja / Suggested citation:}

Murzyn, D. (2019). Rozwój przemysłu poprzez inteligentne specjalizacje i instrumenty polityki regionalnej UE w województwie małopolskim. Prace Komisji Geografii Przemysłu Polskiego Towarzystwa Geograficznego, 33(1), 130-142. https://doi.org/10.24917/20801653.331.10

\section{WSTĘP}

W ostatnich latach nastąpiła redefinicja polityki przemysłowej Unii Europejskiej, a przemysł ma odgrywać istotną rolę w obecnej strategii rozwoju Unii. Proces reindustrializacji jest wspierany przez politykę spójności, m.in. przez współfinansowanie inteligentnych specjalizacji oraz inwestycje, w tym w sektorze przemysłu. Strategie inteligentnych specjalizacji mają pomóc w budowaniu przewag konkurencyjnych regionów na podstawie wewnętrznego potencjału gospodarczego, naukowego i badawczo-rozwojowego, a przy tym wyróżniającego region na tle międzynarodowym. Endogenizacja postępu technicznego i procesy kumulowania specyficznej wiedzy powodują, że produkcja wiedzy stanowi często wspólny produkt z produkcją dóbr, a zdecydowana większość innowacji powstaje w przemyśle.

Celem badań była próba odpowiedzi na pytania, jakie jest miejsce sektora przemysłu w strategii rozwoju Unii Europejskiej i Polski oraz czy i w jakim stopniu polityka wsparcia innowacji poprzez inteligentne specjalizacje może przyczynić się do rozwoju przemysłu w polskich regionach. Badania obejmują analizę źródeł pierwotnych (desk research), takich jak dokumenty programowe i akty prawne Unii Europejskiej i Polski (na poziomie krajowym i regionalnym) - Polska jako największy beneficjent polityki spójności UE może posłużyć jako przykład przełożenia strategii na konkretne działania w państwach członkowskich. Wykorzystano także dane statystyczne Eurostatu i Komisji Europejskiej oraz dane Ministerstwa Inwestycji i Rozwoju dotyczące wykorzystania funduszy UE.

\section{PRZEMYSŁ W STRATEGII ROZWOJU UNII EUROPEJSKIEJ I POLSKI}

Głównym celem polityki przemysłowej jest stymulowanie wzrostu gospodarczego poprzez unowocześnianie, racjonalizację i intensyfikację procesów wytwórczych (Ulbrych, 2013: 50). Związane jest to m.in. z tym, że współcześnie postęp techniczny i innowacyjność mają strategiczne znaczenie, stając się narzędziem wzrostu konkurencyjności gospodarek. Polityka przemysłowa Unii Europejskiej jest ściśle związana z ogólną polityką społeczno-gospodarczą, a na jej treść składają się także inicjatywy podejmowane w obszarach innych polityk, w tym polityki innowacyjnej i polityki regionalnej. Polityka ta przeszła znaczącą ewolucję: od sektorowych interwencji, poprzez wskazywanie „zwycięzców”, ochronę gałęzi raczkujących, na podejściu horyzontalnym skończywszy. Analiza celów, do których dąży polityka przemysłowa, ujętych w strategii Europa 2020, potwierdza kolejną ewolucję podejścia Komisji Europejskiej do sektora przemysłu, które wyraża się w uznaniu za celowe nie tylko działań horyzontalnych, ale również sektorowych (Gawlikowska-Hueckel, 2014). 
Do realizacji priorytetów strategii Europa 2020 przygotowano siedem inicjatyw, w tym inicjatywę: „Zintegrowana polityka przemysłowa w erze globalizacji”. Jej celem jest zapewnienie silnego, konkurencyjnego i zróżnicowanego łańcucha wartości w sektorze produkcji, ze szczególnym uwzględnieniem MŚP, a także pobudzenie wzrostu gospodarczego i tworzenie miejsc pracy poprzez utrzymanie oraz wsparcie silnej, zróżnicowanej i niskoemisyjnej bazy przemysłowej. Do przemysłu odnosi się także inicjatywa flagowa: „Unia innowacji”, której celem jest likwidacja barier hamujących rozwój innowacyjności oraz przeszkód we wprowadzaniu na jednolity rynek UE nowatorskich pomysłów na produkty i usługi, likwidacja niedostatecznego finansowania innowacji, stymulowanie współpracy pomiędzy światem nauki i biznesu. Do osiągnięcia tego celu konieczne jest m.in. zwiększenie konkurencyjności przemysłu unijnego.

Strategiczne znaczenie produkcji przemysłowej jako czynnika wzrostu gospodarczego UE zostało następnie podkreślone w przyjętej w 2012 roku strategii reindustrializacji pt. „Silniejszy przemysł europejski na rzecz wzrostu i ożywienia gospodarczego”. W 2014 roku Komisja Europejska ogłosiła kolejny komunikat pt. „Działania na rzecz odrodzenia przemysłu europejskiego”, w którym po raz kolejny podkreślono konieczność zintegrowanych działań na rzecz wsparcia przemysłu UE. Uczynienie europejskiego przemysłu silniejszym i bardziej konkurencyjnym oraz zmierzanie do tego, aby pozostał on lub stał się światowym liderem innowacji, cyfryzacji i obniżenia emisyjności to cel odnowionej w 2017 roku strategii na rzecz polityki przemysłowej UE, ogłoszonej w komunikacie: „Inwestowanie w inteligentny, innowacyjny i zrównoważony przemysł. Odnowiona strategia dotycząca polityki przemysłowej UE” (COM, 2017). Podkreślono w nim znaczenie silnego i efektywnego przemysłu dla przyszłości europejskiej gospodarki, a także konieczność zwiększenia udziału przemysłu w unijnym PKB z powrotem do $20 \%$ do roku 2020 (sytuację w tym zakresie w poszczególnych krajach UE przedstawia ryc. 1). Istotne jest, by zwiększyć zdolność przemysłu do ciągłej adaptacji i innowacji poprzez ułatwianie inwestycji w nowe technologie i przyswajanie zmian spowodowanych cyfryzacją i przechodzeniem na niskoemisyjną gospodarkę o obiegu zamkniętym.

Ryc. 1. Udział przemysłu w tworzeniu wartości dodanej brutto w Unii Europejskiej w 2017 roku (w \%)

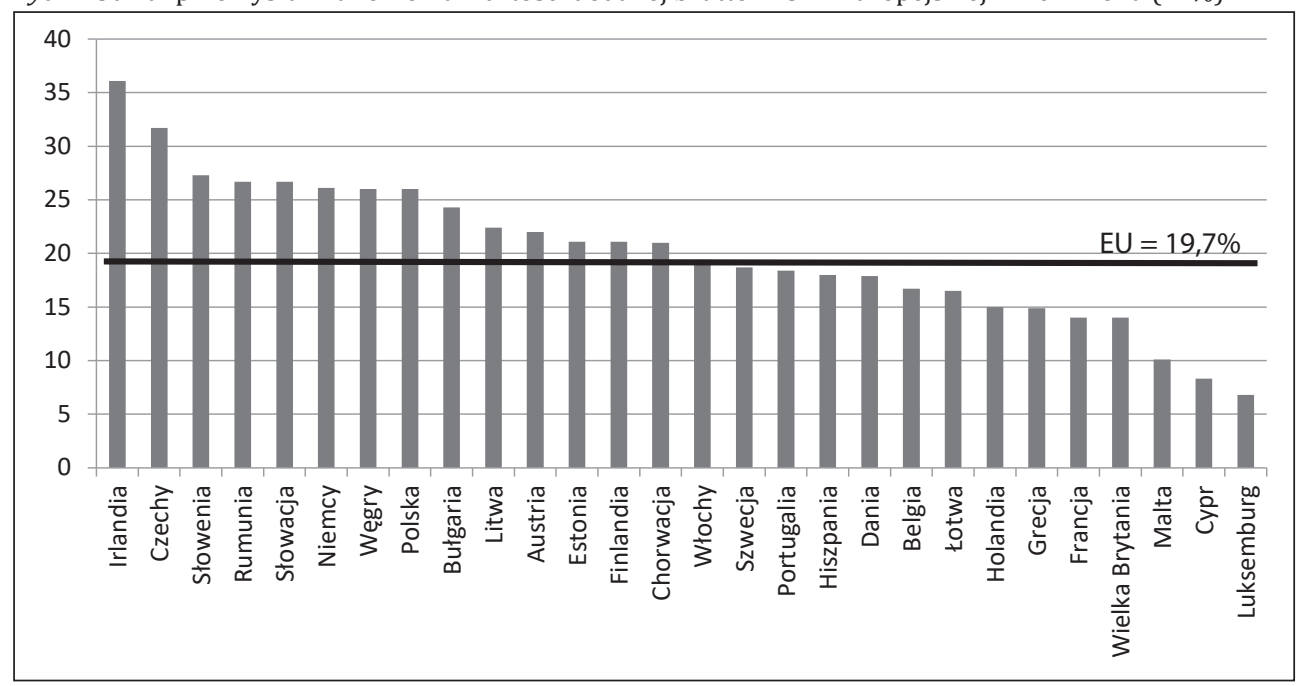

Źródło: Eurostat (2018) 
Jeżeli chodzi o strategię Polski, to w strategii długookresowej, z perspektywą do 2030 roku, niewiele jest odniesień do przemysłu (Ministerstwo Administracji i Cyfryzacji, 2013). Kluczowym dokumentem w obszarze średnio- i długofalowej polityki gospodarczej Polski jest obecnie Strategia na rzecz odpowiedzialnego rozwoju, przyjęta przez Radę Ministrów 14 lutego 2017 roku, która zastąpiła poprzednią strategię z 2012 roku. Poprzednia strategia nie przewidywała precyzyjnie określonych działań na rzecz renesansu przemysłu i wynikało z niej, że nie doceniano możliwości interwencji sektorowych (Gawlikowska-Hueckel, 2014). Obecna strategia określa reindustrializację jako jeden z obszarów wsparcia trwałego wzrostu gospodarczego opartego na wiedzy i doskonałości organizacyjnej. Nowy model rozwoju zakłada odchodzenie od dotychczasowego wspierania wszystkich sektorów i branż na rzecz wspierania sektorów strategicznych mogących stać się motorami polskiej gospodarki. Reindustrializacja ma polegać na „wdrażaniu nowych cyfrowych rozwiązań techniczno-technologiczno-organizacyjnych, jak również rozwoju nowych gałęzi przemysłu opartych na technologiach cyfrowych, zdolnych do tworzenia produktów przełomowych" (Strategia na rzecz odpowiedzialnego rozwoju..., 2017: 10). Realizacja celów strategii ma być osiągana poprzez zaangażowanie środków publicznych krajowych i unijnych - w ramach polityki regionalnej UE. Wymaga to wykorzystania efektów synergicznych polityki przemysłowej i polityki regionalnej UE.

\section{INTELIGENTNE SPECJALIZACJE JAKO NOWY KIERUNEK POLITYKI PRZEMYSŁOWEJ, INNOWACYJNEJ I REGIONALNEJ UE}

Wyrazem tendencji w kierunku „nowych polityk przemysłowych”, które cieszą się zwiększonym zainteresowaniem naukowców w ostatnich latach (Rodrik, 2004), jest strategiczne podejście do polityki oparte na inteligentnych specjalizacjach. Jest ono także charakterystyczne dla polityki innowacyjnej i polityki regionalnej, co odzwierciedla wspólne cele tych polityk.

W traktacie o funkcjonowaniu Unii Europejskiej zapisano, że „Unia i państwa członkowskie czuwają nad zapewnieniem warunków niezbędnych dla konkurencyjności przemysłu Unii" (TFUE, 2012, art. 173). Jednym z działań do osiągnięcia tego celu jest sprzyjanie lepszemu wykorzystaniu potencjału przemysłowego polityk innowacyjnych, badań i rozwoju technologicznego. Celem polityki innowacyjnej jest z kolei wzmacnianie bazy naukowej i technologicznej oraz sprzyjanie rozwojowi konkurencyjności, także w przemyśle (TFUE, 2012, art. 179). Regionalna polityka spójności zmierzać ma natomiast do zwiększania spójności gospodarczej, społecznej i terytorialnej Unii, a w obecnym okresie programowania (2014-2020) ma osiągać ten cel poprzez mechanizm koncentracji tematycznej (m.in. na wzmacnianiu badań naukowych, rozwoju technologicznego i innowacji). Unijne regulacje (załącznik XI do rozporządzenia ogólnego, Rozporządzenie..., 2013) nakładają na państwa członkowskie i regiony obowiązek przygotowania strategii inteligentnej specjalizacji, jest to warunek ex ante korzystania z funduszy polityki spójności (ściślej Europejskiego Funduszu Rozwoju Regionalnego) na innowacje, badania naukowe i rozwój technologiczny. W kontekście strategii Europa 2020 inteligentna specjalizacja regionu jest interpretowana jako kluczowy element lokalnie definiowanych polityk innowacji oraz jest jednym z mechanizmów, za pomocą których cele strategii mają być bezpośrednio realizowane. 
Inteligentna specjalizacja zajmuje szczególne miejsce w przestrzeni polityki innowacji i przemysłu (Foray, 2016), to koncepcja polityki innowacji mająca na celu promowanie efektywnego i skutecznego wykorzystania publicznych inwestycji w badania, innowacje i rozwój technologiczny. Stanowi ramy dla priorytetyzacji alokacji zasobów publicznych związanych z innowacjami, które są wrażliwe na kontekst regionalny. Chociaż nie wszystkie polityki wzrostu oparte na innowacjach lub wiedzy mają komponenty regionalne lub lokalne, rozumienie innowacji ewoluowało z biegiem czasu w tym sensie, że rola odgrywana przez geografię w innowacjach staje się coraz ważniejszym problemem. Inteligentne specjalizacje są sposobem, w jaki polityki sektorowe, takie jak polityka innowacyjna czy przemysłowa, mogą być odpowiednio przełożone na kontekst regionalny. Przejście do inteligentnej specjalizacji jest jedną z kluczowych cech reformy polityki spójności UE. Podejście oparte na inteligentnej specjalizacji oferuje szereg korzyści w zakresie projektowania odpowiedniej polityki tworzenia innowacji, przy jednoczesnym uwzględnieniu różnorodnego ewolucyjnego charakteru gospodarek regionalnych. Inteligentna specjalizacja może być zatem postrzegana jako rezultat długo potrzebnej konwergencji między polityką rozwoju regionalnego a polityką innowacyjności (McCann, 2015).

Koncepcja inteligentnych specjalizacji jest stosunkowo nowa. Wypracowana została w związku z realizacją strategii Europa 2020 przez grupę ekspercką, której pracom przewodniczył unijny komisarz ds. badań Janez Potočnik, natomiast zastępcą przewodniczącego był prof. Dominique Foray. Efektem pracy tej grupy był raport: Knowledge for Growth. European Issues and Policy Challenges (European Comission, 2008). Koncepcja inteligentnej specjalizacji zakłada, że o rozwoju regionu decydują jego potencjał i atuty, tzw. specjalizacje regionu. Podstawą rozwoju jest zidentyfikowanie własnych zasobów, a konsekwencją wyboru dziedzin czy technologii określających specjalizację regionu jest skierowanie interwencji publicznej na inicjatywy i projekty realizowane w ich obszarze.

Podstawy teoretyczne inteligentnych specjalizacji są zawarte w klasycznych teoriach wzrostu gospodarczego (teoria podziału pracy A. Smitha) i w teoriach specjalizacji handlu. Koncepcja ta uwzględnia również badania z zakresu ekonomiki przemysłu i neoklasycznej ekonomiki przestrzennej, a także nawiązuje do teorii rozwoju endogenicznego (opartego na czynnikach wewnętrznych), koncepcji klastrów (podkreślającej bliskość geograficzną współpracujących podmiotów i ich wpływ na rozwój regionu), jak i do teorii bazy ekonomicznej i produktu podstawowego (akcentujących potrzebę specjalizacji produkcyjnej). Istotne są zatem identyfikacja i mobilizacja potencjału endogenicznego w myśl założenia, że każdy region jest zdolny do wzrostu, opierając się na własnych zasobach. Taka identyfikacja pozwala na optymalne wykorzystanie lokalnego potencjału wiedzy, umiejętności, specjalizacji oraz powiązań między podmiotami z uwzględnieniem lokalnych uwarunkowań. Podstawą rozwoju opartego na inteligentnych specjalizacjach jest polityka, której idea zawiera się w place-based-innovation policy, a więc polityce skoncentrowanej terytorialnie ze szczególnym uwzględnieniem innowacji w procesie rozwoju. Koncepcja inteligentnych specjalizacji regionalnych wynika z połączenia polityki sektorowej z regionalną i często nazywana jest swego rodzaju trzecią generacją systemów innowacji (Szostak, 2015). E. Karo i R. Kattel (2015) uważają nawet, że inteligentne specjalizacje są trzecią zewnętrzną i opartą na uwarunkowaniach reformą założeń polityki gospodarczej w Europie Środkowo-Wschodniej w ciągu ostatnich dwóch dekad (po konsensusie waszyngtońskim i europeizacji). 
Nie należy przy tym mylić inteligentnych specjalizacji ze strategiami inteligentnych specjalizacji (Foray, 2015). Procesy związane z inteligentnymi specjalizacjami z sukcesem mogą zachodzić spontanicznie, bez żadnych działań politycznych, dzięki aktywności podmiotów prywatnych zlokalizowanych w regionie. Różnorodność regionalna sprzyja różnym drogom wzrostu poprzez innowacje i specjalizację oraz stawia wyzwania decydentom politycznym w celu opracowania właściwej kombinacji polityki dostosowanej do regionalnych potencjałów i potrzeb (Grillo, Nanetti, 2016). Stąd duża rola regionalnych strategii innowacji i inteligentnych specjalizacji. Regionalne strategie innowacji (RSI) były podstawowym instrumentem realizacji polityki innowacyjnej Unii Europejskiej na poziomie regionalnym w latach 2005-2013. Celem RSI było budowanie przewagi konkurencyjnej regionów i wzmocnienie ich zdolności wykorzystania wiedzy i innowacji, a także zwiększanie konkurencyjności małych i średnich przedsiębiorstw (MŚP) przez wprowadzenie nowych technologii. Nie chodzi przy tym o implementowanie nowych, uważanych za najnowocześniejsze innowacji, ale o rozwijanie i dostosowywanie do nowych warunków branż już w regionie istniejących (Wieloński, Szmigiel, 2006). Kontynuacją RSI stały się narodowe i regionalne strategie badań i innowacji na rzecz inteligentnej specjalizacji (zwane strategiami RIS 3). Stanowią one wyraźny kontrast z wcześniejszymi praktykami politycznymi, które często charakteryzowały się powielaniem skutecznych polityk przyjętych w innych regionach i strategiami „uniwersalnymi dla wszystkich".

Strategie inteligentnej specjalizacji mają na celu promowanie rozwoju nowych regionalnych ścieżek przemysłowych, tj. zmian strukturalnych i gospodarczej dywersyfikacji gospodarek regionalnych (Moodysson, Trippl, Zukauskaite, 2017). Pozwalają na spójne dopasowanie inwestycji w wiedzę i kapitał ludzki do istniejących przemysłowych i technologicznych „kompetencji” terytoriów. Podobnie jak inne podejścia do nowej polityki przemysłowej, inteligentna specjalizacja zawiera elementy tzw. zarządzania eksperymentalnego (Sabel, Zeitlin, 2012), kładzie nacisk na ustalanie celów polityki w ścisłej interakcji z jej adresatami, mechanizmy uczenia się i odpowiedzialność za pośrednictwem wzajemnej oceny (tzw. proces przedsiębiorczego odkrywania).

\section{INTELIGENTNE SPECJALIZACJE WOJEWÓDZTWA MAŁOPOLSKIEGO A ROZWÓJ PRZEMYSŁU}

W celu rozpoczęcia procesu priorytetyzacji polityki inteligentna specjalizacja wymaga zatem szczegółowej analizy obecnej regionalnej struktury gospodarczej i przemysłowej na podstawie najlepszych dostępnych informacji. Podstawowym dokumentem przygotowanym dla kreatorów regionalnych strategii innowacji na rzecz inteligentnych specjalizacji jest „Przewodnik strategii badań i innowacji na rzecz inteligentnej specjalizacji (RIS 3)" (Foray i in., 2013). Zgodnie z wytycznymi Komisji Europejskiej Polska zidentyfikowała inteligentne specjalizacje na poziomie krajowym i regionalnym. Ogólne ramy strategiczne dla krajowych inteligentnych specjalizacji w Polsce zawiera Strategia innowacyjności i efektywności gospodarki „Dynamiczna Polska” (SIiEG), spójna z unijną strategią rozwoju Europa 2020 oraz zapisami średniookresowej Strategii rozwoju kraju 2020. Dokumentem wykonawczym do SIiEG jest Program rozwoju przedsiębiorstw do 2020 roku, który zawiera kompleksowy katalog instrumentów wsparcia rozwoju innowacyjności i przedsiębiorczości w Polsce. Jego integralną część stanowi Krajowa inteligentna specjalizacja (KIS). Wdrażanie Krajowej inteligentnej specjalizacji 
odbywa się zarówno przez realizację programów krajowych (np. projekty Narodowego Centrum Badań i Rozwoju, Polskiej Agencji Rozwoju Przedsiębiorczości), jak i przy wykorzystaniu środków unijnych w ramach programów operacyjnych, głównie programu operacyjnego „Inteligentny rozwój”. Ponadto każdy region (województwo) opracował swoją regionalną strategię dot. inteligentnych specjalizacji.

Określenie własnej tożsamości społeczno-gospodarczej to najtrudniejsze zadanie wpisane w wymóg inteligentnej specjalizacji. Regiony mają tendencję do naśladowania rozwiązań przyjętych na obszarach, które odniosły sukces gospodarczy. Istotne znaczenie dla wyłonienia inteligentnych specjalizacji regionalnych w Małopolsce miało przeprowadzenie cyklu badań regionalnych typu foresight w latach 2006-2010. Zarys małopolskich inteligentnych specjalizacji został przedstawiony w Regionalnej strategii innowacji województwa małopolskiego 2014-2020. Do dziedzin specjalizacji zaliczono: nauki o życiu, energię zrównoważoną, technologie informacyjne i komunikacyjne, w tym multimedia (ICT), chemię, produkcję metali i wyrobów metalowych (z wyłączeniem maszyn i urządzeń), elektrotechnikę i przemysł maszynowy oraz przemysły kreatywne i czasu wolnego. Identyfikacja inteligentnych specjalizacji zbiega się z identyfikacją tych branż, w których region się specjalizuje - takie podejście może prowadzić do regionalnej strategii rozwoju opartej na procesie odnowy przemysłowej.

Szczegółowy opis obszarów małopolskich inteligentnych specjalizacji został opracowany przez grupy robocze ds. małopolskich inteligentnych specjalizacji i przedstawiony w dokumencie: „Inteligentne specjalizacje województwa małopolskiego. Uszczegółowienie obszarów wskazanych w Regionalnej strategii innowacji województwa małopolskiego 2014-2020". Obszary regionalnej inteligentnej specjalizacji oraz ich zakres podlegają okresowemu przeglądowi i aktualizacji w oparciu o system monitorowania Regionalnej strategii innowacji województwa małopolskiego oraz zachodzące zmiany społeczno-gospodarcze.

Zgodnie z zapisami Regionalnej strategii innowacji województwa małopolskiego 2014-2020 grupy robocze wspólnie z Małopolską Radą Innowacji stanowią najważniejszy element systemu, w ramach którego kontynuowany jest tzw. proces przedsiębiorczego odkrywania w regionie. Proces ten realizowany jest w formule poczwórnej helisy (Höglund, Linton, 2017), angażując przede wszystkim przedsiębiorców, a także przedstawicieli nauki, instytucji otoczenia biznesu, administracji oraz użytkowników innowacji. Proces przedsiębiorczego odkrywania realizowany dla potrzeb regionalnej strategii innowacji (RIS 3) jest rozbudowaną metodą strategicznego zarządzania regionem (Dziedzic, Woźniak, Czerepiuk, 2016).

W obrębie poszczególnych dziedzin wytyczonych przez inteligentne specjalizacje regionu działa ponad 33 tys. podmiotów (tab. 1). To przede wszystkim przedsiębiorstwa, ale także jednostki naukowo-badawcze oraz instytucje otoczenia biznesu. Najsilniej reprezentowane są przemysły kreatywne oraz czasu wolnego, które stanowią ok. $42 \%$ wszystkich podmiotów, najmniej (poniżej 1\%) - energia zrównoważona i chemia. Te pierwsze stanowią najbardziej zróżnicowaną grupę, obejmują m.in.: podmioty prowadzące działalność w zakresie architektury, oprogramowania, agencje reklamowe, restauracje i inną działalność gastronomiczną, obiekty noclegowe, działalność portali internetowych. 
Tab. 1. Liczba podmiotów działających w obrębie regionalnych inteligentnych specjalizacji w województwie małopolskim

\begin{tabular}{|l|c|c|}
\hline \multicolumn{1}{|c|}{ Inteligentna specjalizacja } & $\begin{array}{c}\text { Liczba podmiotów } \\
\text { (w tym przedsiębiorstw) }\end{array}$ & $\begin{array}{c}\text { Udział procentowy } \\
\text { w ogóle podmiotów } \\
\text { inteligentnych } \\
\text { specjalizacji }\end{array}$ \\
\hline Nauki o życiu & $10591(10566)$ & $31,94 \%$ \\
\hline Energia zrównoważona & $206(199)$ & $0,61 \%$ \\
\hline Technologie informacyjne i komunikacyjne & $1193(1179)$ & $3,60 \%$ \\
\hline Chemia & $265(249)$ & $0,80 \%$ \\
\hline Produkcja metali i wyrobów metalowych & $3717(3705)$ & $11,21 \%$ \\
\hline Elektrotechnika i przemysł maszynowy & $3234(3227)$ & $9,75 \%$ \\
\hline Przemysły kreatywne oraz czasu wolnego & $13957(13935)$ & $42,09 \%$ \\
\hline Razem & $33163(33060)$ & $100,00 \%$ \\
\hline
\end{tabular}

Źródło: opracowanie własne na podstawie Charakterystyka dziedzin... (2018) oraz Charakterystyka 3 spośród 7 dziedzin... (2018)

Przygotowanie uszczegółowienia związane było pośrednio z koniecznością określania zgodności z małopolskimi inteligentnymi specjalizacjami projektów ubiegających się o dofinansowanie z Regionalnego programu operacyjnego województwa małopolskiego (MRPO) na lata 2014-2020 w ramach osi priorytetowej 1. Gospodarka wiedzy oraz osi priorytetowej 3. Przedsiębiorcza Małopolska. Celem osi priorytetowej 1 jest wzrost innowacyjności gospodarki regionalnej, wyrażający się głównie zwiększeniem nakładów na działalność badawczo-rozwojową. Wspierane są interwencje przyczyniające się do wzmacniania badań naukowych, rozwoju technologicznego i innowacji, właśnie w obszarach inteligentnej specjalizacji Małopolski. Na te działania przeznaczono ponad 230 mln euro z Europejskiego Funduszu Rozwoju Regionalnego. Z kolei celem osi priorytetowej 3 jest budowanie i wzmacnianie pozycji konkurencyjnej sektora MŚP. Dzięki realizowanym przedsięwzięciom ma się zwiększyć wyposażenie regionu w infrastrukturę sprzyjającą rozwijaniu działalności gospodarczej oraz lokowaniu inwestycji, wzmocniony zostanie system wspierania przedsiębiorczości, w szczególności w obszarach regionalnej specjalizacji, a także zwiększona zostanie rola instrumentów zwrotnych we wsparciu działalności inwestycyjnej MŚP. Alokacja na te działania to 240 mln euro.

Przyglądając się jednak dotychczasowemu wykonaniu tych działań (na podstawie danych Ministerstwa Inwestycji i Rozwoju, stan na 30 września 2018 roku), możemy zauważyć, że zaledwie 9\% podmiotów, które uzyskały dofinansowanie z MRPO, to podmioty działające w obrębie regionalnych inteligentnych specjalizacji w województwie małopolskim. Stanowi to zaledwie 1\% podmiotów uprawnionych w tym zakresie (patrz tab. 1). Oznacza to, że po środki w ramach działań współfinansowanych z funduszy unijnych sięgają przede wszystkim podmioty spoza branż bezpośrednio związanych z inteligentnymi specjalizacjami regionu. Zakładając, że wszystkie projekty, które uzyskały dofinansowanie, muszą być zgodne z RSI, można wnioskować, że inteligentne specjalizacje bardziej służą wspieraniu polityki innowacyjnej (koncentrują środki na działalność badawczo-rozwojową w pewnych obszarach) niż polityki przemysłowej. Wynika to także z analizy przeznaczenia środków na poszczególne działania (ryc. 2). 
Ryc. 2. Wartość projektów i wartość dofinansowania UE w ramach poszczególnych działań MRPO odnoszących się do inteligentnych specjalizacji regionu (w mln zł)

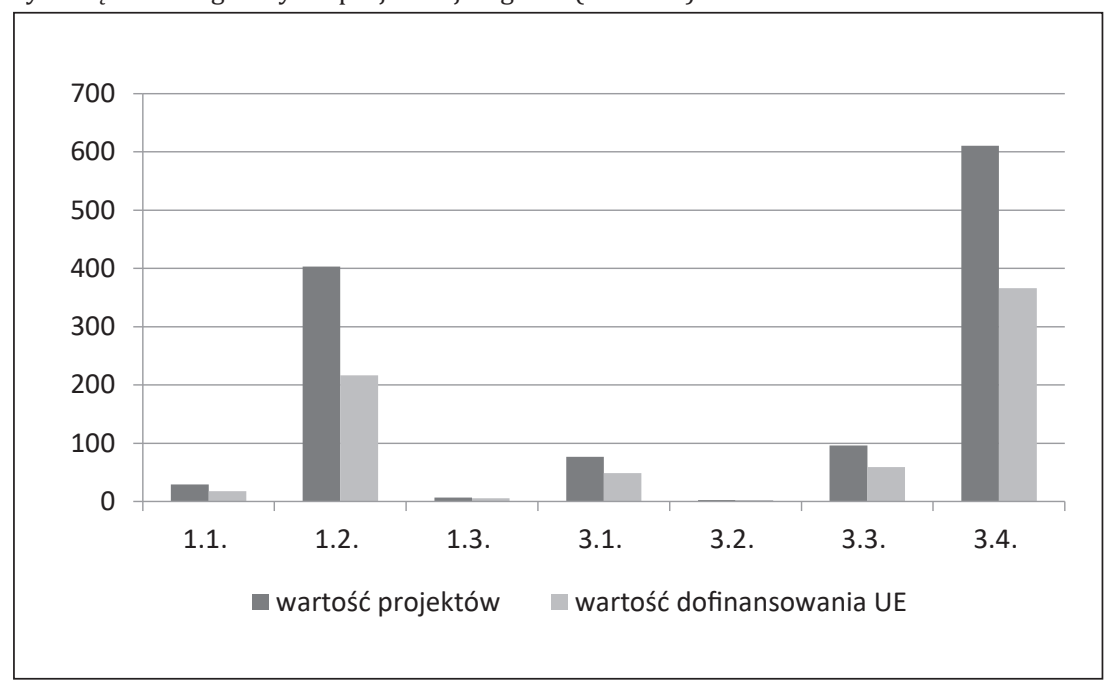

1.1. Infrastruktura badawcza sektora nauki. 1.2. Badania i innowacje w przedsiębiorstwach. 1.3. Małopolskie centra innowacji. 3.1. Strefy aktywności gospodarczej. 3.2. Promocja postaw przedsiębiorczych oraz potencjał IOB. 3.3. Umiędzynarodowienie małopolskiej gospodarki. 3.4. Rozwój i konkurencyjność małopolskich MŚP.

Źródło: opracowanie własne na podstawie bazy projektów Małopolskiego Regionalnego Programu Operacyjnego (stan na 30 września 2018 roku)

Najwięcej funduszy przeznaczono na działanie 3.4. Rozwój i konkurencyjność małopolskich MŚP. W ramach tego działania przewidziano wsparcie przedsiębiorstw w sposób bezpośredni - poprzez dotacje, oraz pośredni - poprzez rozwój instrumentów finansowych (zwrotnych) i zakup przez MŚP specjalistycznych usług doradczych. Z rozdysponowanych w konkursach 366,34 mln zł, pochodzących z Europejskiego Funduszu Rozwoju Regionalnego, bezpośrednio do przedsiębiorstw trafiło 99,14 mln zł (czyli zaledwie 27\%). Najwięcej natomiast zostało przeznaczone na tworzenie instrumentów finansowych przez Bank Gospodarstwa Krajowego (265,79 mln zł z EFRR). Jest to zgodne z założeniami polityki UE, w myśl której zwiększa się rolę instrumentów finansowych, w szczególności w zakresie wsparcia przedsiębiorstw. Podstawową zaletą instrumentów zwrotnych jest możliwość wykorzystania tzw. efektu mnożnikowego, czyli możliwości kilkukrotnego (rewolwingowego) wykorzystania danej puli środków. Przekazane wsparcie, w odróżnieniu od systemu dotacyjnego, podlega bowiem zwrotowi, a tym samym zastosowanie instrumentów inżynierii finansowej daje możliwość udzielenia wsparcia większej ilości potencjalnych beneficjentów niż miałoby to miejsce w przypadku pomocy bezzwrotnej. Oprócz oczywistych korzyści, wynikających z recyrkulacji funduszy w dłuższej perspektywie czasu, instrumenty finansowe pomagają w mobilizowaniu dodatkowych inwestycji publicznych lub prywatnych w celu wypełniania luk rynkowych zgodnie z priorytetami strategii Europa 2020 i polityki spójności.

Szczególne znaczenie dla przedsiębiorstw mają także działania 1.2. Badania i innowacje w przedsiębiorstwach oraz 3.3. Umiędzynarodowienie małopolskiej gospodarki. W ramach pierwszego z nich wsparcie kierowane jest na: projekty badawczo-rozwojowe 
przedsiębiorstw; projekty obejmujące utworzenie lub rozwój infrastruktury laboratoriów, działów badawczo-rozwojowych lub centrów badawczo-rozwojowych w przedsiębiorstwach oraz wzmacnianie współpracy MŚP z sektorem naukowo-badawczym i proinnowacyjnym otoczeniem biznesu, a także zapewnienie podmiotom z sektora MŚP dostępu do wysokiej jakości usług badawczo-rozwojowych i proinnowacyjnych. Łącznie na te cele rozdysponowano 216,61 mln zł z EFRR. Z kolei umiędzynarodowienie małopolskiej gospodarki dokonywane jest dwutorowo poprzez: promocję gospodarczą Małopolski oraz wsparcie aktywności międzynarodowej MŚP. Tylko w tym drugim przypadku wsparcie kierowane jest bezpośrednio do przedsiębiorstw, wyniosło ono 20,68 mln zł (ok. 35\% całości środków w ramach tego działania).

W pozostałych działaniach beneficjentami były uczelnie (utworzenie Centrum Badawczo-Rozwojowego Wydziału Chemii Uniwersytetu Jagiellońskiego w ramach działania 1.1), województwo małopolskie (SPIN - małopolskie centra transferu wiedzy - jedyny projekt, który uzyskał dofinansowanie w działaniu 1.3), jednostki samorządu terytorialnego (strefy aktywności gospodarczej), instytucje otoczenia biznesu i inne podmioty (promocja postaw przedsiębiorczych i profesjonalizacja usług doradczych instytucji otoczenia biznesu). Zatem łącznie na bezpośrednie wsparcie przedsiębiorstw w ramach priorytetu 1 i 3 przekazano 336,44 mln zł z EFRR, co stanowiło ok. 47\% rozdysponowanych do tej pory środków na cele związane z inteligentnymi specjalizacjami regionu.

Inteligentne specjalizacje niekoniecznie odzwierciedlają wzrost względnej wagi danej branży (przemysłu). Odzwierciedlają raczej zdolność regionalnego systemu ekonomicznego do generowania nowych obszarów rozwoju poprzez odkrywanie nowych możliwości oraz lokalną koncentrację zasobów i kompetencji w wybranych dziedzinach. Tworzą możliwości i napędzają zmiany strukturalne. Rozwój regionalny jest złożonym procesem, który wymaga synergicznego połączenia różnych aktywów wzrostu. Inteligentne specjalizacje powinny wspierać i być powiązane z projektami rozwoju terytorialnego, które nie wymagają wąskiego zaangażowania poszczególnych branż, ale muszą wykorzystywać specyfikę i osobliwości tego, co zostało nazwane kapitałem terytorialnym (Camagni, 2009; Capello, Kroll, 2016).

W najsłabiej ekonomicznie rozwijających się regionach, o mniej solidnych zasadach zarządzania, a zwłaszcza w Europie Wschodniej, RIS 3 często okazują się być bardzo trudnym zadaniem. Stawiają duże wymagania wobec niestabilnych lub ograniczonych ram instytucjonalnych, ale jednocześnie oferują realne możliwości instytucjonalnego uczenia się i podnoszenia zdolności zarządzania (McCann, Ortega-Argilés, 2016). Jest to szczególnie istotne dla rozwiązania regionalnego paradoksu innowacji, pokazującego większą potrzebę regionów zapóźnionych do inwestowania w innowacje i ich relatywnie mniejszą zdolność do absorpcji finansowania w porównaniu z bardziej zaawansowanymi regionami (Oughton, Landabaso, Morgan, 2002). Rozwiązanie tego paradoksu będzie wymagało ciągłych inwestycji w mechanizm zarządzania, aby zwiększyć regionalną zdolność innowacyjną i w pełni wykorzystać potencjał strategii inteligentnej specjalizacji (Muscio, Reid, Rivera-Leon, 2015).

\section{ZAKOŃCZENIE}

Analiza dokumentów strategicznych UE i Polski oraz danych statystycznych potwierdza rosnące znaczenie przemysłu dla rozwoju gospodarczego. Do tego sektora odnoszą się dwie flagowe inicjatywy realizowane w ramach strategii Europa 2020: „Polityka 
przemysłowa w erze globalizacji” i „Unia innowacji”. Ta druga zwraca szczególną uwagę na innowacje i wsparcie działalności badawczo-rozwojowej, w tym w przedsiębiorstwach przemysłowych. Zdecydowano przy tym o konieczności określenia priorytetów gospodarczych w obszarze B+R+I oraz skupienia na nich inwestycji. Wskazanie inteligentnych specjalizacji regionów było warunkiem dostępu do środków unijnych na inwestycje wspierające rozwój badań i wdrażanie innowacji w latach 2014-2020. Strategie inteligentnych specjalizacji w Polsce to z jednej strony reakcja na możliwość pozyskania środków z Unii Europejskiej, z drugiej zaś szansa na realną rekonstrukcję standardowej strategii rozwoju regionalnego i polityki przemysłowej.

Zakres inteligentnych specjalizacji poszczególnych regionów Polski jest zróżnicowany, a już sam proces ich identyfikacji był dla województw wyzwaniem. Małopolska wybrała siedem inteligentnych specjalizacji, na które przeznaczyła ok. 1,5 mld zł w ramach regionalnego programu operacyjnego (prawie połowa alokacji na cały program), będącego najważniejszym instrumentem realizacji unijnej polityki regionalnej w województwie. Analiza wykorzystania tych środków pokazuje, że trafiają one jednak przede wszystkim do podmiotów spoza branż bezpośrednio związanych z inteligentnymi specjalizacjami regionu. Inteligentne specjalizacje bardziej służą zatem wspieraniu polityki innowacyjnej (koncentrują środki na działalność badawczo-rozwojową w pewnych obszarach) niż polityki przemysłowej.

Z drugiej strony, środki polityki regionalnej pozwalają przedsiębiorstwom inwestować w rozwój zaawansowanych technologii, a przez to wpływają na modernizację przemysłu. Efektywność tych działań będzie większa, jeśli koncepcja inteligentnej specjalizacji będzie właściwie interpretowana i wdrażana, wówczas może stanowić szansę dla rozwoju przemysłu w polskich regionach.

\section{Literatura}

\section{References}

Camagni, R. (2009). Territorial capital and regional development. W: R. Capello, P. Nijkamp (red.). Handbook of regional growth and development theories. Cheltenham: Edward Elgar, 118132.

Capello, R., Kroll, H. (2016). From theory to practice in smart specialization strategy: emerging limits and possible future trajectories. European Planning Studies, 24(8), 1393-1406.

Charakterystyka 3 spośród 7 dziedzin wytyczonych przez inteligentną specjalizację regionu i rozpoznanie oczekiwań przedsiębiorstw działających $w$ tych dziedzinach $(2018,18$ października). Pozyskano z https://www.malopolska.pl/publikacje/gospodarka/charakterystyka-3-sposrod-7-dziedzin-wytyczonych-przez-inteligentna-specjalizacje-regionu

Charakterystyka dziedzin wytyczonych przez inteligentnq specjalizację regionu (2018, 18 października). Pozyskano z https://www.malopolska.pl/publikacje/gospodarka/charakterystyka-dziedzin-wytyczonych-przez-inteligentna-specjalizacje-regionu

COM (2017, 13 września). 479 final. Inwestowanie w inteligentny, innowacyjny i zrównoważony przemysł. Odnowiona strategia dotyczaca polityki przemysłowej UE. Bruksela.

Dziedzic, S., Woźniak, L., Czerepiuk, P. (2016). Proces przedsiębiorczego odkrywania jako metoda strategicznego planowania i implementacji inteligentnych specjalizacji regionu. Prace Naukowe Uniwersytetu Ekonomicznego we Wrocławiu, 444, 107-118.

European Commission (2008). Knowledge for Growth. European Issues and Policy Challenges. Luxembourg.

Eurostat (2018, 10 października). Pozyskano z: http://appsso.eurostat.ec.europa.eu/nui/submitViewTableAction.do 
Foray, D. (2015). Smart Specialisation: Opportunities and Challenges for Regional Innovation Policy. Abingdon: Routledge/Regional Studies Association.

Foray, D. (2016). On the policy space of smart specialization strategies. European Planning Studies, 24(8), 1428-1437.

Foray, D., Goddard, J., Beldarrain, X.G., Landabaso, M., McCann, P., Morgan, K., Nauwelaers, C., Ortega-Argilès, R. (2013). Przewodnik strategii badań i innowacji na rzecz inteligentnej specjalizacji (RIS3). Komisja Europejska.

Gawlikowska-Hueckel, K. (2014). Polityka przemysłowa i spójności wobec planów reindustrializacji Unii Europejskiej. Wnioski dla Polski. Gospodarka Narodowa, 5(273), 53-80.

Grillo, F., Nanetti, R.Y. (2016). Innovation, Democracy and Efficiency: Exploring the Innovation Puzzle within the European Union's Regional Development Policies. Houndmills, Basingstoke, Hampshire, New York: Palgrave Macmillan.

Höglund, L., Linton, G. (2018). Smart specialization in regional innovation systems: a quadruple helix perspective. R\&D Management, 48(1), 60-72.

Karo, E., Kattel, R. (2015). Economic development and evolving state capacities in Central and Eastern Europe: Can „smart specialization” make a difference? Journal of Economic Policy Reform, 18(2), 172-187.

McCann, P. (2015). The region al and Urban Policy of the European Union. Cohesion, results-orientation and smart specialization. Cheltenham, Northampton: Edward Elgar.

McCann, P., Ortega-Argilés, R. (2016). The early experience of smart specialization implementation in EU cohesion policy. European Planning Studies, 24(8), 1407-1427.

Ministerstwo Administracji i Cyfryzacji (2013, 11 stycznia). Polska 2030. Trzecia fala nowoczesności. Długookresowa strategia rozwoju kraju. Warszawa.

Moodysson, J., Trippl, M., Zukauskaite, E. (2017). Policy learning and smart specialization: balancing policy change and continuity for new regional industrial paths. Science and Public Policy, 44(3), 382-391.

Muscio, A., Reid, A., Rivera-Leon, L. (2015). An empirical test of the regional innovation paradox: can smart specialisation overcome the paradox in Central and Eastern Europe? Journal of Economic Policy Reform, 18(2), 153-171. DOI: 10.1080/17487870.2015.1013545 2015

Oughton, C., Landabaso, M., Morgan, K. (2002). The Regional Innovation Paradox: Innovation Policy and Industrial Policy. The Journal of Technology Transfer, 27, 97-110.

Rodrik, D. (2004). Industrial Policy for the Twenty-First Century. Cambridge, MA: John F. Kennedy School of Government.

Rozporządzenie Parlamentu Europejskiego i Rady (UE) nr 1303/2013 z dnia 17 grudnia 2013 roku ustanawiające wspólne przepisy dotyczące Europejskiego Funduszu Rozwoju Regionalnego, Europejskiego Funduszu Społecznego, Funduszu Spójności, Europejskiego Funduszu Rolnego na rzecz Rozwoju Obszarów Wiejskich oraz Europejskiego Funduszu Morskiego i Rybackiego oraz ustanawiające przepisy ogólne dotyczące Europejskiego Funduszu Rozwoju Regionalnego, Europejskiego Funduszu Społecznego, Funduszu Spójności i Europejskiego Funduszu Morskiego i Rybackiego oraz uchylające rozporządzenie Rady (WE) nr 1083/2006, 0J L 347 (2013, 20 grudnia).

Sabel, C., Zeitlin, J. (2012). Experimentalist Governance. W: D. Levi-Faur (red.). The Oxford Handbook of Governance. Oxford: Oxford University Press, 169-83.

Strategia na rzecz odpowiedzialnego rozwoju do roku 2020 (z perspektywą do 2030 roku), przyjęta przez Radę Ministrów dnia 14 lutego 2017 roku (M.P. poz. 260).

Szostak, E. (2015). Inteligentne specjalizacje w rozwoju regionu. Studia Ekonomiczne, 209, 209218.

Traktat o funkcjonowaniu Unii Europejskiej (TFUE), wersja skonsolidowana (Dz. Urz. UE C 326 z 26 października 2012 r.).

Ulbrych, M. (2013). Priorytety polityki przemysłowej w Unii Europejskiej wobec wyzwań kryzysu globalnego. Prace Komisji Geografii Przemysłu Polskiego Towarzystwa Geograficznego, $21,47-62$.

Wieloński, A., Szmigiel, K. (2006). Regionalne strategie innowacji jako czynnik aktywizacji polskiej przestrzeni przemysłowej. Prace Komisji Geografii Przemysłu Polskiego Towarzystwa Geograficznego, 9, 20-27. 
Dorota Murzyn, dr, adiunkt w Katedrze Ekonomii i Polityki Gospodarczej Instytutu Prawa, Administracji i Ekonomii Uniwersytetu Pedagogicznego w Krakowie. W badaniach naukowych koncentruje się wokół polityki spójności Unii Europejskiej i jej oddziaływania na rozwój gospodarczy Polski, ponadto jej zainteresowania badawcze obejmują: integrację europejską, finanse publiczne, politykę gospodarczą. Uczestnik wielu projektów badawczych z tego zakresu. Autorka książek i artykułów nt. determinant i kierunków wpływu funduszy UE na rozwój inteligentny, zrównoważony i inkluzywny w Polsce.

Dorota Murzyn, PhD, assistant professor in the Department of Economics and Economic Policy, Institute of Law, Administration and Economics, Pedagogical University of Cracow. Her research focuses on the EU's cohesion policy and its impact on the economic development of Poland, moreover her research interests include European integration, public finance, economic policy. She has been involved in many research projects in this field. Author of books and articles on determinants and directions of impact of EU funds on smart, sustainable and inclusive development in Poland.

ORCID: 0000-0003-2032-8401

\section{Adres/address:}

Uniwersytet Pedagogiczny w Krakowie Instytut Prawa, Administracji i Ekonomii Katedra Ekonomii i Polityki Gospodarczej ul. Podchorążych 2/234, 30-084 Kraków, Polska e-mail: dorota.murzyn@up.krakow.pl 